\title{
PRODUKSI BIONANOMINERAL SELENIUM DARI BERBAGAI JENIS STRAIN BAKTERI ASAM LAKTAT (BAL) SEBAGAI ADITIF PADA RANSUM TERNAK RUMINANSIA
}

\section{Production of Selenium Bionanomineral by Various Strains of Lactic Acid Bacteria (LAB) as Feed Additives for Ruminant}

\author{
Rizki Amalia Nurfitriani'1, Roni Ridwan², Anuraga Jayanegara ${ }^{3}$, Nur Rochmah \\ Kumalasari $^{3}$, Santi Ratnakomala ${ }^{2}$, dan Yantyati Widyastuti ${ }^{2}$ \\ ${ }^{1}$ Program Studi Produksi Ternak, Jurusan Peternakan, Politeknik Negeri Jember. \\ 2Pusat Penelitian Bioteknologi, Lembaga Ilmu Pengetahuan Indonesia \\ ${ }^{3}$ Departemen Ilmu Nutrisi dan Teknologi Pakan, Fakultas Peternakan, IPB University \\ Email: ranurfitriani@polije.ac.id
}

\begin{abstract}
INTISARI
Penelitian ini bertujuan untuk mengetahui produksi bionanomineral Selenium (Se) dari berbagai jenis strain Bakteri Asam Laktat (BAL) dan potensinya sebagai mineral organik untuk ternak ruminansia. Metode yang dilakukan terdiri dari penyiapan alat dan bahan, pengembangbiakan BAL, pembuatan dan pengamatan produksi bionanomineral Se. Perlakuan penelitian terdiri dari 2 tahap yaitu tahap pertama terdiri dari 4 perlakuan strain BAL berbeda: TSD10, SPCE, DR162, dan IA2, tahap 2 masing-masing strain BAL diberikan perlakuan dosis 25 ppm dan 50 ppm. Parameter yang diamati diantaranya, Tahap 1: produksi Bionanomineral yang dihasilkan oleh intraseluler bakteri dan ekstraseluler bakteri. Tahap 2: Optical Density (OD) bakteri dan $\mathrm{pH}$. Rancangan penelitian ini menggunakan rancangan penelitian deskriptif kuantitatif. Hasil penelitian menunjukkan bahwa produksi bionanomineral ekstraseluler lebih banyak dihasilkan dibandingkan dengan intraseluler, penambahan 25 sampai $50 \mathrm{ppm}$ Se menunjukkan OD ke empat strain bakteri bertahan hidup, serta hasil $\mathrm{pH}$ bervariasi dari masingmasing strain bakteri namun masih dalam kisaran normal. Kesimpulan dari penelitian ini yaitu produksi bionanomineral Se terbanyak dengan dosis $25 \mathrm{ppm}$ dan $50 \mathrm{ppm}$ pada berbagai jenis strain BAL berbeda diperoleh pada bagian ekstraseluler dengan strain IA2 sebesar 0,3584 g. Nilai OD dari keempat strain BAL masih mampu bertahan hidup pada penambahan dosis Se 25 ppm sampai $50 \mathrm{ppm}$. Nilai $\mathrm{pH}$ yang dihasilkan bervariasi namun tetap pada kisaran normal yaitu berkisar antara 5 sampai 6 . Dilihat dari produksi yang dihasilkan oleh BAL menunjukkan bahwa bionanomineral Se berpotensi sebagai sumber mineral Se organik untuk feed additive ternak ruminansia.
\end{abstract}

Kata kunci: Bakteri Asam Laktat, Bionanomineral, Selenium, dan Ternak Ruminansia

\begin{abstract}
This study aimed to determine the production of bionanomineral Selenium (Se) from various types of Lactic Acid Bacteria (LAB) strains and its potential as an organic mineral for ruminants. The method used consisted of preparing tools and materials, LAB incubation, making and observing the production of bionanomineral Se. The research treatment consisted of 2 steps, namely the first step was 4 treatments of different LAB strains: TSD10, SPCE, DR162, and IA2.The twice step was each $L A B$ strain was given a treatment dose of $25 \mathrm{ppm}$ and $50 \mathrm{ppm}$. The parameters observed included bionanomineral production produced by both intracellular bacteria and extracellular bacteria, Optical Density (OD) of bacteria and $p H$. The research design used a quantitative descriptive research design. The results showed that extracellular bionanomineral production was more than intracellular. The observation of OD showed that the addition of 25 to $50 \mathrm{ppm}$ Se, four strains of bacteria be able to survive. The conclusion of this study were the highest bionanomineral Se production at a dose of $25 \mathrm{ppm}$ and $50 \mathrm{ppm}$ in various types of different LAB strains was the extracellular section with the IA2 strain $(0.3584 \mathrm{~g})$. The OD values of the four LAB strains were still able to survive at the addition of a Se dose of $25 \mathrm{ppm}$ to $50 \mathrm{ppm}$. The $\mathrm{pH}$ value from each bacterial
\end{abstract}


strain was varied but were still in the normal range (5 up to 6). Based on the production produced by $L A B$, it shows that bionanomineral Se has the potential as a source of organic Se minerals for ruminant feed additives.

Keywords: Lactic Acid Bacteria, Bionanomineral, Selenium, and Ruminants

\section{PENDAHULUAN}

Mikroba rumen dapat berkembang dengan baik apabila diberikan nutrien yang baik salah satunya pemberian mineral. Fungsi mineral sangat penting dalam aktivitas mikroba rumen tetapi umumnya belum banyak mendapat perhatian khususnya dalam metabolisme rumen. Pakan dengan kombinasi pemberian mineral secara optimal dapat memberikan pengaruh terhadap sistem ekologi rumen dengan memperbaiki produktivitas, status kesehatan, serta performa ternak (Biswas and Biswas, 2012).

Salah satu mineral penting dalam rumen yaitu Selenium (Se). Se dalam pakan ruminansia tidak hanya diberikan untuk ternak tetapi juga untuk bakteri rumen yang mampu memanfaatkan Se dalam metabolisme rumen (Serra et al., 1994). Pemberian Se dalam bentuk anorganik akan beresiko mengalami keracunan, sehingga perlu ada konversi Se anorganik menjadi organik, sehingga aman untuk dikonsumsi ternak.

Salah satu teknologi konversi Se anorganik menjadi organik yaitu bionanomineral. Biomineral merupakan suatu komponen mineral yang dihasilkan dari mikroba rumen ternak yang diberi pakan mengandung mineral. Cairan rumen mengandung zat makanan seperti protein, vitamin, mineral dan lain-lain yang diproduksi mikroba rumen. Potensi nutrien dari cairan rumen ini dapat dimanfaatkan dan diolah menjadi suplemen biomineral (Tjakradidjaja dan Bakrie, 2007). Nanoteknologi merupakan ilmu yang mempelajari mengenai struktur suatu materi yang berukuran nano $\left(10^{-9} \mathrm{~m}\right)$ (Kurnia et al., 2012).

Bionanomineral merupakan suatu pembentukkan nano mineral yang dihasilkan oleh mikroorganisme (Bhuvaneshwari et al., 2011). Mikroba yang umum digunakan untuk pembuatan bionanomineral adalah bakteri asam laktat (BAL). Respon bakteri dalam pembentukan bionanomineral belum diketahui untuk setiap strain BAL, baik dari produksi hingga karakteristik bakteri. Oleh karena itu, perlu diteliti lebih lanjut mengenai produksi bionanomineral Se dari berbagai strain BAL. Penelitian ini bertujuan untuk mengetahui produksi bionanomineral Se dari berbagai jenis strain BAL serta potensinya untuk diberikan pada ternak ruminansia.

\section{MATERI DAN METODE}

Rancangan penelitian menggunakan rancangan deskriptif kuantitatif. Penelitian ini dilakukan di Laboratorium Mikrobiologi Terapan, Pusat Peneltian Bioteknologi, Lembaga Ilmu Pengetahuan Indonesia (LIPI) Cibinong, Bogor.

\section{Alat dan Bahan}

Alat yang digunakan dalam penelitian ini yaitu Erlenmeyer, autoclave, tabung reaksi untuk persiapan bakteri (Tahap I). Botol schott, erlenmeyer $500 \mathrm{ml}$, sentrifuge, micro tube, neraca analitik, laminar air flow cabinet, corning $250 \mathrm{ml}$, shaker, autoclave, micropipet p1000, microtip p1000, dan bunsen burner untuk pembuatan bionanomineral (Tahap II). Bahan yang digunakan diantaranya de Man, Rogosa and Sharpe broth (MRS broth) cair, Selenium oksida $\left(\mathrm{SeO}_{3}\right)$, BAL dengan strain TSD10, SPCE, IA2, dan DR162.

\section{Prosedur Penelitian}

1. Pengembangbiakan BAL

Sebanyak 1-2 lup masing-masing strain bakteri diinokulasikan pada $5 \mathrm{ml}$ media MRS cair dan diinkubasi selama 24 jam sebagai sub 
kultur, kemudian dikulturkan ke media MRS cair dengan menambahkan 10\% hasil inkubasi ke dalam MRS cair yang baru tersebut dan diinkubasi kembali selama 24 jam. Hasil inkubasi tersebut dikulturkan kembali ke media MRS cair $50 \mathrm{ml}$ media MRS cair dengan perlakuan yang sama.

2. Pehitungan Dosis $25 \mathrm{ppm}$ dan $50 \mathrm{ppm}$ Se Penambahan dosis Se dalam inokulasi BAL dilakukan dengan konversi $\mathrm{SeO}_{3}$. Konversi untuk mendapatkan dosis $25 \mathrm{ppm}$ dan 50 ppm dihitung sebagai berikut:

$$
\begin{aligned}
\text { Massa } & \mathrm{SeO}_{3} \rightarrow \mathrm{Se}+(\mathrm{O})_{3} \\
& =78,96 \mathrm{~g} / \mathrm{mol}+(15,999 \mathrm{~g} / \mathrm{mol})^{3} \\
& =78,96 \mathrm{~g} / \mathrm{mol}+47,997 \mathrm{~g} / \mathrm{mol} \\
& =126,957 \mathrm{~g} / \mathrm{mol} \\
& =126,96 \mathrm{~g} / \mathrm{L}
\end{aligned}
$$

$\%$ Se dalam $\mathrm{SeO}_{3}=\frac{\mathrm{Se} \times 100}{\text { Total Massa SeO3 }}$

$$
\begin{aligned}
& =\frac{78,96 \mathrm{~g} / \mathrm{mol} \mathrm{x} 100}{126,957 \mathrm{~g} / \mathrm{mol}} \\
& =62,19 \%
\end{aligned}
$$

\section{Konversi 25 ppm Se}

$$
\begin{aligned}
25 \mathrm{ppm} \mathrm{Se} & =\frac{25 \times 1000 \mathrm{~g}}{1.000 .000} \\
& =0,025 \mathrm{~g} \mathrm{Se}
\end{aligned}
$$

$\mathrm{SeO}_{3}$ yang dibutuhkan untuk memperoleh 25 ppm Se

$$
\begin{aligned}
25 \text { ppm } & =\frac{\text { Massa SeO3 x Berat Se } 25 \mathrm{ppm}}{\text { Massa Se }} \\
& =\frac{126,96 \mathrm{~g} / \mathrm{L} \times 0,025 \mathrm{~g}}{78,96 \mathrm{~g} / \mathrm{L}} \\
& =0,0402 \mathrm{~g} \mathrm{SeO}_{3}
\end{aligned}
$$

\section{Konversi 50 ppm Se}

$$
\begin{aligned}
50 \mathrm{ppm} \mathrm{Se} & =\frac{50 \times 1000 \mathrm{~g}}{1.000 .000} \\
& =0,05 \mathrm{~g} \mathrm{Se}
\end{aligned}
$$

$\mathrm{SeO}_{3}$ yang dibutuhkan untuk memperoleh 50 ppm Se

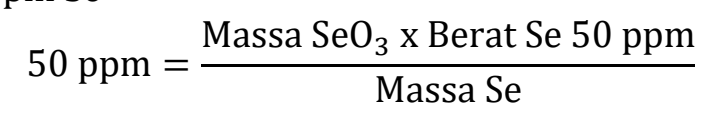

$$
\begin{aligned}
& =\frac{126,96 \mathrm{~g} / \mathrm{L} \mathrm{x} \mathrm{0,05g}}{78,96 \mathrm{~g} / \mathrm{L}} \\
& =0,0804 \mathrm{~g} \mathrm{SeO}_{3}
\end{aligned}
$$

\section{Pembuatan Bionanomineral Se}

Pembuatan bionanomineral Se dengan isolat BAL (strain TSD 10, SPCE, IA2, dan DR162) merupakan modifikasi metode dari Eszenyi et al., (2011). Selenium oksida $\left(\mathrm{SeO}_{3}\right)$ ditimbang sesuai hasil perhitungan dan dimasukkan ke kultur isolat dalam media kultur. Erlenmeyer ditutup rapat dengan kapas, kain kassa dan karet gelang. Kultur isolat diinkubasi pada suhu ruang selama 3 hari dengan pengocokkan dalam shaker kecepatan $120 \mathrm{rpm}$. Setelah 3 hari kultur isolat diambil $200 \mathrm{ml}$. Kultur disentrifugasi pada kecepatan 6000 rpm selama 10 menit. Supernatan dan endapan yang terbentuk dipisahkan, kemudian endapan dikoleksi. Endapan kultur dicuci dengan aquades diautoklaf untuk mendapatkan nanomineral selenium ekstraseluler.

Supernatan kultur yang dihasilkan disentrifugasi pada kecepatan $2500 \mathrm{rpm}$ selama 15 menit. Endapan yang terbentuk dibuang, sedangkan supernatan disentrifugasi kembali pada kecepatan $13.000 \mathrm{rpm}$ selama 15 menit. Endapan yang didapat merupakan senyawa selenium intraseluler yang kemudian dicuci dengan aquades steril sebanyak 3 kali. Supernatan kultur disentrifugasi kembali pada kecepatan $10.000 \mathrm{rpm}$ selama 15 menit. Supernatan dan endapan yang terbentuk dipisahkan, dan endapan dicuci dengan aquades steril sebanyak 3 kali dengan bantuan sentrifuge pada $13.000 \mathrm{rpm}$ selama 10 menit. Endapan yang terbentuk merupakan senyawa nanomineral ekstraseluler dan kemudian disimpan beserta supernatannya. Senyawa mineral ekstraseluler dan intraseluler ditimbang beratnya.

4. Pengamatan Produksi Bionanomineral, Optical Density (OD), dan pH

Pengamatan produksi bionanomineral ditimbang menggunakan timbangan digital 
dan dicatat berat bionanomineral untuk intraseluler dan ekstraseluler. OD diamati dengan menggunakan spektrofotometri, serta pengamatan $\mathrm{pH}$ menggunakan $\mathrm{pH}$ meter dengan dikalibrasi terlebih dahulu.

\section{HASIL DAN PEMBAHASAN}

\section{Produksi Bionanomineral Ekstraseluler dan Intraseluler dari Berbagai Jenis Strain BAL}

Berdasarkan hasil pengamatan diperoleh bahwa produksi bionanomineral terbanyak terdapat pada bagian ekstraseluler. Strain bakteri yang memproduksi bagian ekstraseluler bionanomineral terbanyak yaitu IA2 sebesar 0,3584 g, sedangkan produksi terkecil terdapat pada BAL dengan strain SPCE sebesar 0,0000 (Gambar 1.). Hal ini bertolak belakang dengan produksi bionanomineral bagian intraseluler. Strain SPCE menunjukkan produksi terbesar yaitu $0,0163 \mathrm{~g}$, sedangkan produksi terkecil yaitu strain IA2 dengan berat 0,0023 g. Hal ini diduga karena sistem kinetika dari masingmasing strain bakteri berbeda.

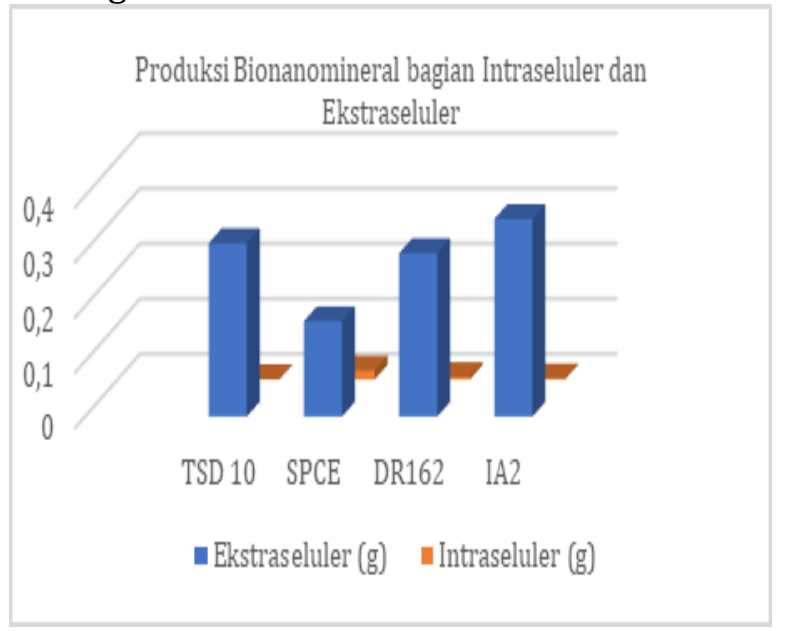

Gambar 1. Produksi bionanomneral pada bagian intraseluler dan ekstraseluler.

Teuber (2008) menyatakan bahwa bakteri anaerob mampu memproduksi dan mengakumulasi unsur selenium pada bagian ekstraseluler. $\quad$ Formatting Citation\} menyatakan bahwa zat polimer ekstraseluler mikroba atau yang disebut Eksopolisakarida (EPS), terdiri dari polisakarida, protein, asam nukleat, dan lipid yang memiliki salah satu fungsi menarik ion disekitarnya, salah satunya selenium, sehingga produksi bionanomineral Se lebih banyak terdapat di ekstraseluler. Salah satu kelebihan pembuatan bionanomineral Se yaitu terbukti sangat tahan terhadap suhu tinggi dan tekanan (tidak ada perubahan kimiawi selama sterilisasi pada suhu $121^{\circ} \mathrm{C}$ selama 20 menit.

Karakteristik ini yang membedakan dengan produksi dengan sintesis kimiawi (Eszenyi et al., 2011). Selain itu, teknologi bionano ini lebih efektif karena hasilnya relatif teratur dan ukurannya relatif seragam, proses produksi lebih murah dan cepat, sehingga berpotensi untuk dijadikan sebagai suplemen pakan dan aditif. Interaksi mikroba dengan mineral yaitu transformasi reduktif dari oksigenasi, misalnya Se (VI) ke Se (IV) ke Se (0); Se (0) oksidasi; biometilasi dan demetilasi senyawa Se; asimilasi senyawa Se dan anorganik. Proses metabolisme Se oleh mikroba menghasilkan imobilisasi dan detoksifikasi (reduksi $\mathrm{SeO}_{2}$ menjadi $\mathrm{Se}(0)$ ). (Gadd, 2010).

Biomineralisasi mengacu pada proses kolektif oleh organisme mana yang membentuk mineral. Sintesis mineral bisa dikategorikan ke dalam mineralisasi yang diinduksi secara biologis dan mineralisasi yang dikendalikan secara biologis. Mineralisasi yang diinduksi secara biologis terjadi ketika sebuah organisme memodifikasi penciptaan lingkungan mikro lokalnya dengan sedemikian rupa sehingga hasilnya akan membentuk bahan kimia ekstraseluler pada fase pengendapan mineral (Gadd, 2010). Produk metabolit ekstraseluler bakteri dipengaruhi oleh kondisi lingkungan seperti suhu, $\mathrm{pH}$, nutrisi dan lainnya (Mora-Villalobos et al., 2020).

\section{Nilai Optical Density (OD)}

Optical density (OD) digunakan sebagai pengukuran proxy cepat suatu konsentrasi pada biomassa tersuspensi. Pengukuran OD adalah pengukuran yang paling umum digunakan di laboratorium mikrobiologi untuk menilai pertumbuhan mikroba (Myers 
et al., 2013). Hasil pengamatan OD menunjukkan bahwa keempat strain BAL masih mampu bertahan hidup pada penambahan dosis Se 25 ppm sampai 50 ppm yang disajikan pada Gambar 2 .

Hal ini dapat diartikan bahwa keempat strain tersebut dapat digunakan sebagai mikroba yang mampu memproduksi bionanomineral Se. Genus Lactobacillus termasuk dalam genus bakteri asam laktat (BAL) yang memiliki berbagai macam sifat fenotipik, biokimia, dan fisiologis (Smetanková et al., 2018).

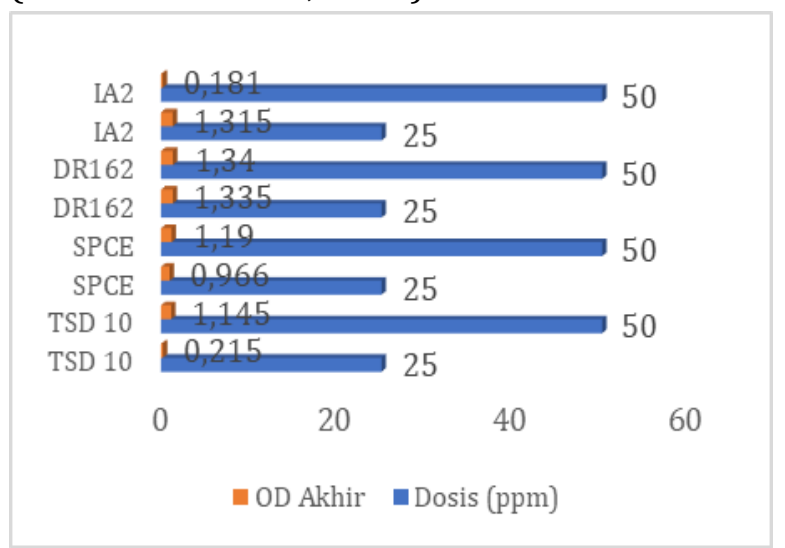

Gambar 2. OD Berbagai Jenis Strain BAL dengan Dosis Bionanomineral Se Berbeda.

Strain BAL mampu bertahan dalam memfermentasi mineral Se dikarenakan mineral tersebut merupakan salah satu komponen nutrien yang umum dimanfaatkan oleh BAL. Mineral digunakan oleh Lactobacillus plantarum untuk pembentukan biomassa dan untuk menekan oksigen reaktif (Wegkamp et al., 2010).

\section{Nilai pH setelah Inkubasi Bionanomineral Se dari Strain BAL Berbeda}

Pengamatan nilai $\mathrm{pH}$ pada hasil inkubasi BAL umumnya digunakan untuk melihat kemampuan bakteri dalam mereduksi $\mathrm{pH}$ lingkungan dan daya tahan terhadap bakteri 24patogen (Kareem et al., 2014). Semakin rendah nilai $\mathrm{pH}$ menunjukkan produksi asam laktat yang semakin tinggi. Asam laktat diproduksi untuk meningkatkan pertumbuhan sel. Selain itu, aktivitas enzimatis bakteri patogen dapat dirusak oleh asam yang dihasilkan oleh BAL 24dengan memanfaatkan sisa energi untuk menghilangkan kelebihan ion $\mathrm{H}^{+}$, dimana ion tersebut yang nantinya akan dimanfaatkan oleh bakteri 24 patogen (Kareem et al., 2014). Hasil pengamatan pH pada hasil inkubasi beberapa jenis strain BAL cenderung menurun (Tabel 1).

Tabel 1. Nilai pH Hasil Inkubasi Beberapa Strain BAL Berbeda dengan Dosis Se Berbeda

\begin{tabular}{clcr}
\hline No. & Bakteri & Dosis (ppm) & $\mathrm{pH}$ \\
\hline 1 & TSD 10 & 25 & 3,44 \\
2 & SPCE & 25 & 5,16 \\
3 & DR162 & 25 & 4,08 \\
4 & IA2 & 25 & 5,71 \\
\hline 5 & TSD 10 & 50 & 3,64 \\
6 & SPCE & 50 & 4,72 \\
7 & DR162 & 50 & 4,4 \\
8 & IA2 & 50 & 3,45 \\
\hline
\end{tabular}

Hal ini menunjukkan bahwa produksi asam laktat meningkat setelah masa inkubasi selesai. Penambahan mineral Se mempercepat penuruan $\mathrm{pH}$. Wiander and Ryhänen (2005) menyatakan bahwa penambahan mineral dalam fermentasi BAL akan menurunkan $\mathrm{pH}$ dengan cepat. Fermentasi tersebut dilakukan oleh BAL dengan menggunakan strain Lactobacillus plantarum dalam kondisi aerobik dan anaerobik. Bahan media yang mengandung laktosa digunakan sebagai media kultur. Fermentasi anaerobik menghasilkan asam laktat yang lebih tinggi (sebanyak 2,3 kali lipat) untuk fermentasi aerobik pada $\mathrm{pH}$ optimum berkisar antara 5 dan 6 (Smetanková et al., 2018).

\section{KESIMPULAN}

Produksi bionanomineral Se terbanyak dengan dosis 25 ppm dan 50 ppm pada berbagai jenis strain BAL berbeda diperoleh pada bagian ekstraseluler dengan strain IA2 sebesar 0,3584 g. Nilai OD dari keempat strain BAL masih mampu bertahan hidup pada penambahan dosis Se 25 ppm sampai $50 \mathrm{ppm}$. Nilai $\mathrm{pH}$ yang dihasilkan bervariasi namun tetap pada kisaran normal yaitu berkisar 
antara 5 sampai 6. Dilihat dari produksi yang dihasilkan oleh BAL menunjukkan bahwa bionanomineral Se berpotensi sebagai sumber mineral Se organik untuk feed additive ternak ruminansia.

\section{UCAPAN TERIMA KASIH}

Ucapan terima kasih penulis sampaikan kepada Laboratorium Mikrobiologi Terapan, Pusat Penelitian Bioteknologi Gedung Peternakan, Lembaga Ilmu Pengetahuan Indonesia (LIPI) yang telah memberikan dukungan dalam penyediaan dana dan pelaksanaan penelitian di LIPI Cibinong.

\section{DAFTAR PUSTAKA}

Bhuvaneshwari, B. Sasmal, and N.R. Iyer. 2011. Nanoscience to nanotechnology for civil engineering: proof of concepts. Proceedings of the 4th WSEAS international conference on Energy and development - environment biomedicine. 11(1):230-235.

Biswas, P.K., and P. Biswas. 2012. In vitro evaluation of a diet supplemented with mn on nutrient digestibility and rumen fermentation pattern in cattle. Exploration Animal and Medicine Research. 1(2) :161-166.

Eszenyi, P., A. Sztrik, B. Babka, and J. Prokisch. 2011. Elemental, nano-sized (100-500 $\mathrm{nm}$ ) selenium production by probiotic lactic acid bacteria. International Journal of Bioscience, Biochemistry and Bioinformatics. 1(2):148-152.

Gadd, G.M. 2010. Metals, minerals and microbes: geomicrobiology and bioremediation. Microbiology. 156(3):609-643.

Kareem, K.Y., F.H. Ling, L.T. Chwen, O.M. Foong, and S.A. Asmara. 2014. Inhibitory activity of postbiotic produced by strains of Lactobacillus plantarum using reconstituted media supplemented with inulin. Gut Pathogens. 6(1):1-7.

Kim, H.J., H.J. Eom, C. Park, J. Jung, B. Shin, W. Kim, N. Chung, I.G. Choi, and W. Park. 2015. Calcium carbonate precipitation by Bacillus and sporosarcina strains isolated from concrete and analysis of the bacterial community of concrete. Journal of Microbiology and Biotechnology. 26(3):540-548.

Kurnia, F., M. Suhardiman., L, Stephani, dan T, Purwadaria. 2012. Peranan nanomineral sebagai bahan imbuhan pakan untuk meningkatkan produktivitas dan kualitas produk ternak. Wartazoa. 22(4):187-193.

Mora-Villalobos, J.A., J. Montero-Zamora, N. Barboza, C. Rojas-Garbanzo, J. Usaga, M. Redondo-Solano, L. Schroedter, A. Olszewska-Widdrat, and J.P. LopezGomez,. 2020. Multi-product lactic acid bacteria fermentations: a review. Fermentation. 6(1):23.

Myers, J.A., B.S. Curtis, and W.R. Curtis. 2013. Improving accuracy of cell and chromophore concentration measurements using optical density. BMC biophysics. 6(1):4.

Serra, A.B., K. Nakamura, T. Matsui, T. Harumoto, and T. Fujihara. 1994. Inorganic selenium for sheep I. Selenium balance and selenium levels in the different ruminal fluid fractions. Asian-Australasian Journal of Animal Sciences. 7(1):83-89.

Smetanková, J., Z. Hladíková, F. Valach, M. Zimanová, Z. Kohajdová, G. Greif, and M. Greifová. 2018. Influence of aerobic and anaerobic conditions on the growth and metabolism of selected strains of Lactobacillus plantarum. Acta Chimica Slovaca. 5(2):204-210.

Teuber, M. 2008. Lactic Acid Bacteria. Biotechnology. 1(12):325-366.

Tjakradidjaja, A.S. dan B. Bakrie. 2007. Pengolahan dan pemanfaatan cairan rumen limbah rumah potong hewan di DKI Jakarta sebagai biomineral. Ringkasan Eksekutif Pusat Penelitian dan Pengembangan Pertanian Republik Indonesia. 99-100.

Wegkamp, A., B. Teusink, W.M. De Vos, and E.J. Smid, 2010. Development of a minimal growth medium for Lactobacillus plantarum. Applied Microbiology. 50(1):57-64.

Wiander, B. and E.L. Ryhänen. 2005. Laboratory and large-scale fermentation of white cabbage into sauerkraut and sauerkraut juice by using starters in combination with mineral salt with a 
low $\mathrm{NaCl}$ content. European Food Research and Technology. 220(2):191195. 